A Patient with COVID-19 Presenting a False-Negative Reverse Transcriptase \section{Polymerase Chain Reaction}

\section{Result}

\author{
Zuhua Chen, $M D^{1}$, Yunjiang Li, MD', \\ Baoliang $\mathrm{Wu}, \mathrm{MD}^{1}$, Yanchun Hou, $M D^{1}$, \\ Jianfeng Bao, $M D^{2}$, Xueying Deng, $M D^{3}$
}

Departments of ${ }^{1}$ Radiology and ${ }^{2}$ Science and Education, The Hangzhou Xixi Hospital, Zhejiang Chinese Medical University, Hangzhou, China; ${ }^{3}$ Department of Radiology, The Cancer Hospital of the University of Chinese Academy of Sciences, Hangzhou, China

Dear Editor,

We read with interest an article by Li et al. (1), who present two patients with coronavirus disease 2019 (COVID-19), but with a negative reverse-transcriptase polymerase chain reaction (RT-PCR) test result. In this letter, we want to present a similar case of severe COVID-19 in both lungs with an initially negative RT-PCR test.

On February 10, 2020, a 63-year-old man presented to the hospital with a 13-day history of fever and fatigue due to an unknown cause. The patient had a fever since January 27,2020 . At that time, he was not aware of the emergence of 2019-nCoV; therefore, instead of going to hospital, he continued to work and visit his neighbors. He worked as an employee in the property management company of his residential community until he was hospitalized. On January

Received March 3, 2020; accepted after revision March 9, 2020. Corresponding author: Xueying Deng, MD, Department of Radiology, The Cancer Hospital of the University of Chinese Academy of Sciences (Zhejiang Cancer Hospital), Banshandong Road 1\#, Hangzhou 310000, China.

- Tel: (860571) 88122186 - Fax: (860571) 88122186

- E-mail: a1145047838@163.com

This is an 0pen Access article distributed under the terms of the Creative Commons Attribution Non-Commercial License (https://creativecommons.org/licenses/by-nc/4.0) which permits unrestricted non-commercial use, distribution, and reproduction in any medium, provided the original work is properly cited.
29, he accompanied his wife to a local hospital due to a slight fever presented to his wife, who had experienced upper respiratory symptoms intermittently since last month. Then on February 5, 7, and 9, he went to a local farmer's market for daily shopping.

On February 10, 2020, he finally presented to a local general hospital in Hangzhou. He was highly under suspicion of having pneumonia related to the 2019$n C o V$ infection and was transferred to isolation in the Xixi Hospital of Hangzhou, Zhejiang Province, China, the national authority responsible for the management of 2019$\mathrm{nCoV}$ infectious diseases.

On admission, the patient presented with fever, fatigue, decreased appetite, and an occasional dry cough. He denied travelling to Wuhan or any exposure to infected patients. He had undergone surgery of the duodenal papillary carcinoma 17 years ago. His body temperature was elevated to $37.5^{\circ} \mathrm{C}$ $\left(99.5^{\circ} \mathrm{F}\right)$ and coarse breath sounds were heard in both lungs at auscultation. Laboratory studies showed elevation of C-reactive protein (203 mg/L; normal range, $0-10 \mathrm{mg} / \mathrm{L}$ ), procalcitonin $(0.100 \mathrm{ng} / \mathrm{mL}$; normal range, $0-0.5 \mathrm{ng} / \mathrm{mL})$, and D-dimer (1.13 mg/L; normal range, $0-0.55 \mathrm{mg} / \mathrm{L})$. The white blood cell differential count showed $80.0 \%$ neutrophils and $9.9 \%$ lymphocytes. Unenhanced chest computed tomography (CT) scan manifested multiple peripheral lesions in both lungs. This patient contained all the characteristics of pneumonia (2) caused by 2019-nCoV. Some of the lesions presented with pure ground-glass opacity (GGO) (Fig. 1A), GG0 with interlobular septal thickening (Fig. 1B), GG0 with consolidation (Fig. 1C), or prominent consolidation (Fig. 1D). Most of the lesions were contained with consolidated composition, and no lung cavitation, pleural effusions, or lymphadenopathy were found. However, despite a long disease course and extensive lung lesions, this patient's first RT-PCR result was negative, indicating a low sputum viral load.

On February 12, another RT-PCR test was performed, which showed a weak positive for the 2019-nCoV nucleic acid. The patient received symptomatic treatment and oxygen therapy. On February 13, another chest CT was performed, which presented a slight increase of the consolidation. He remained hospitalized in a relatively stable condition.

In this case, the patient presented with extensive lesions in both lungs, but with a negative RT-PCR test result. 


\section{KJR}

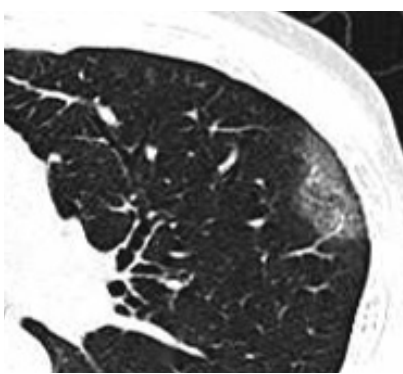

A

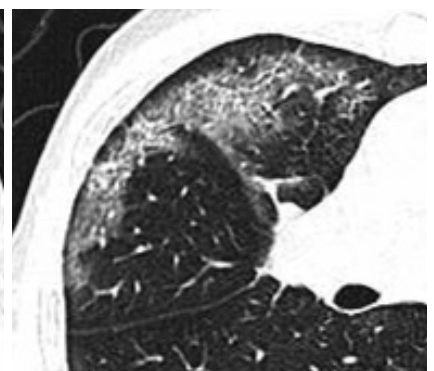

B
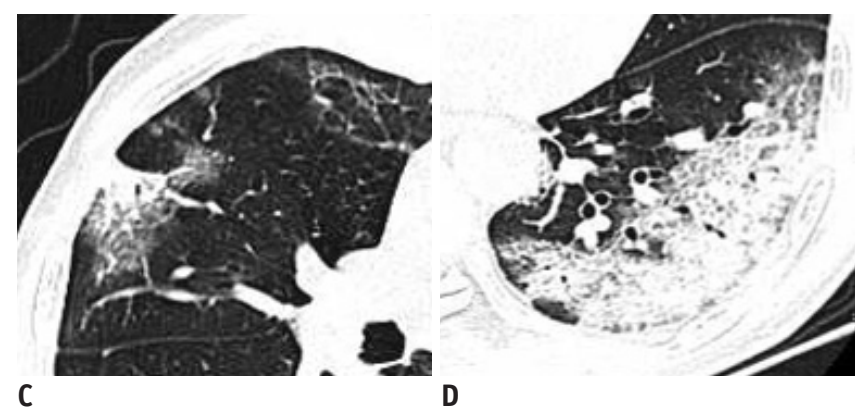

Fig. 1. Different presentations of lesions in both lungs of patient.

A. Pure GG0 in left upper lobe. B. GG0 with interlobular septal thickening in both right upper and middle lobe.

C. GGO with consolidation in right upper lobe. D. Mostly consolidation lesions in left inferior lobe. $\mathrm{GGO}=$ ground-glass opacity

Despite this negative result, the patient was also infectious. His wife, son (a 27-year-old bus driver), and his wife's brother (who stayed at their home celebrating the Spring Festival) were also confirmed as infected with 2019-nCoV.
Such situations are likely to be universal in the clinical environment, and we should be aware of potential falsenegative RT-PCR results.

\section{ORCID iDs}

Xueying Deng

https://orcid.org/0000-0002-2683-3460

Zuhua Chen

https://orcid.org/0000-0003-0389-5180

\section{REFERENCES}

1. Li D, Wang D, Dong J, Wang N, Huang H, Xu H, et al. Falsenegative results of real-time reverse-transcriptase polymerase chain reaction for severe acute respiratory syndrome coronavirus 2: role of deep-learning-based CT diagnosis and insights from two cases. Korean J Radiol 2020;21:e37

2. Song F, Shi N, Shan F, Zhang Z, Shen J, Lu H, et al. Emerging 2019 novel coronavirus (2019-nCoV) pneumonia. Radiology 2020 Feb 6 [Epub]. https://doi.org/10.1148/ radiol.2020200274 